\title{
Sales Promotion, Hedonic Shopping Value, and Impulse Buying on Online Consumer Websites
}

\author{
Sesilya Kempa ${ }^{1 *}$, Kevin Vebrian ${ }^{1}$, and Hakim Bendjeroua ${ }^{2}$ \\ ${ }^{1}$ Faculty of Business and Economics, Petra Christian University, Siwalankerto 121-131, \\ Surabaya 60236, Indonesia \\ ${ }^{2}$ Departement of Sciences of Management, Faculty of Economics, Management and Commercial \\ Sciences, Kasdi Merbah University - Ouargla Ghardaia Road, BP.511, 30,000, Algeria
}

\begin{abstract}
The phenomenon in the increasing fashion business is caused by online shopping activity, especially in fashion products. In this research, shopping activity is focused on online shopping. Online shopping is also called internet shopping, electronic shopping, online buying, or buying through the internet. Online shopping has become the newest trend for Indonesian as an alternative to buying a product or service. Advertisement and trend are able to influence consumers in doing or deciding to buy. This is the reason people buy excessively unplanned as needed. This research purpose is to observe the sales promotion influence toward impulse buying with hedonic shopping value as intervening to fashion online shopping consumers in Surabaya. This research uses 99 respondents, and the data analysis uses the Partial Least Square (PLS) model. The result shows that sales promotion and hedonic shopping value have significant positive influence on impulse buying. Moreover, hedonic shopping value as variable intervening has an influence between sales promotion to impulse buying.
\end{abstract}

Keywords: Hedonic shopping value, impulse online buying, online sales promotion.

\section{Introduction}

The fashion industry is a dynamic business industry. This is marked with the uncertain demand as a result of consumers' various styles and high taste; with this fact, it is impossible to predict the demand accurately. The fashion sector contributes $1.44 \%$ in PDB Indonesia. Some factors such as the increasing consumers' purchasing power in Indonesia especially in special occasions like Idul Fitri, Christmas, Chinese New Year; the increasing of population; the increasing of income per capita; and the increasing number of middle class society to high class society in Indonesia support the Indonesia retail growth [1].

Fashion is always an interesting topic to discuss because it is one of the primary human needs. Every human being wears clothes and footwear everyday in every activity. It encourages people to have more than one clothes and footwear. Besides, the seasonal

\footnotetext{
${ }^{*}$ Corresponding author: sesilya.kempa@petra.ac.id
} 
fashion change pushes them to keep buying. That is why the fashion retail section is always developing bigger [2].

Industry Minister states that the fashion industry has an important role more and more in the national economy. The industry that is one of the creative industries contributes $3.76 \%$ of national PDB in 2017. In this period, the fashion industry export reaches USD $13.29 \times 10^{9}$ or increasing $8.7 \%$ from the year before [3].

The increasing fashion business phenomenon is caused by the increasing in shopping activity, especially in fashion products. In this research, shopping activity is focused on the activity of online shopping. Online shopping is also called internet shopping, online buying, or buying from the internet.

Lai and Sung explains that there is a rapid growth in the activity of online shopping [4]. Online shopping becomes a new consumption method for consumers nowadays. Ahmad et al., say that online shopping is considered as time, effort and money exchange to receive products or services [5]. In recent years, online shopping has become a norm, and the consumers of every country prefer it because it has some advantages compared to offline shopping. This becomes the new trend of the alternative in doing transactions for Indonesian people.

In doing shopping activity, consumers must be influenced by a certain value. Ridha and Prabowo explain that the basic value in doing shopping can be hedonism or utilitarianism value [6]. This study focuses on hedonism. Ardyansyah and Arifin say that hedonism value is something that pushes someone to fulfill his/her desire based on material pleasure or enjoyment as the main focus neglecting the main priority [7].

Advertisement and trend influence consumers in buying or deciding to buy. That is the reason for someone to excessively buy unnecessary products unplanned [7]. This excessive purchase is usually influenced by a stimulating offer from a retailer [8]. Andryansyah and Arifin say that the desire to change and social influence make someone motivated to buy unplanned purchase [7]. This condition happens because of social or environment influence that makes someone decides to purchase what is not on the shopping list. This behavior is usually called impulse buying.

The impulse behavior of an individual is influenced by the desire to fulfill his/her needs right now. The desire when seeing the offered product has higher chances for someone to buy it impulsely [9]. In this research, impulse buying activity is described by a sudden unplanned purchase, which is done through an e-commerce website. Because the online buyer has double roles as a traditional buyer and internet user, so the motivation and dimension of impulse buying come from the online shopping [4].

The impulse buying behavior is also influenced by sales promotion, which is done by the seller. Amanah and Pelawi explain that interesting promotion triggers consumers' impulse buying [10]. For example, the bundling promotion offers a discount or offers discounted free stuff for the next purchase. This type of promotion is effective to stimulate the consumer to do impulse buying, especially for consumer who likes to do shopping.

This study refers to some previous research related to hedonic shopping value, sales promotion, and impulse buying variables. Andryansyah and Arifin relate hedonic shopping value and impulse buying [7]. The research is done to shoppers in a mall and from the observation, hedonic shopping value is one of the factors of impulse buying. According to Amanah and Pelawi, who also do their research in a mall, state that there is another factor indicating the impulse buying, it is the sales promotion done by the seller [10].

The other research is done by Windiarto, he studies the influence of hedonic shopping value to impulse buying with the consumers of Carrefour Ambarukmo Plaza Yogyakarta [11]. The study shows that basically, hedonic shopping value has a positive influence significantly to the consumers. There is a contradiction study titled The Analysis of the Influence of Impulse Buying towards Shopping Lifestyle and Possitive Emotion as an 
Intervening Variable at Ciputra World Mall Surabaya by Darma and Japrianto [12]. Therefore, there is no significant influence between hedonic shopping value and impulse buying. Another research is by Kwan [13] titled The Influence of Sales Promotion and Store Atmosphere towards Impulse Buying and Positive Emotion as an Intervening Variable at Planet Sports Tanjungan Plaza Surabaya, according to him, sales promotion gives significant and positive influence toward impulse buying at the place.

\section{Literature review}

\subsection{Sales promotion}

Amanah and Pelawai [10] say that sales promotion is related to the short term purpose to stimulate the purchase or the selling of a product or service. This purpose is related to reward, whether it is in a discount, cashback purchase, warranty or a sample product, etc. Sales promotion is a marketing effort to encourage buyer candidates to buy more and frequently. The point is that sales promotion is an earnest effort to build a mutual relationship with consumers long term.

\subsection{Impulse buying}

Impulse buying usually happen when someone is visiting a place where everything is available, from the basic needs to what he/she wants, such as a mall or supermarket. Impulse buying is an unplanned shopping behavior of someone that happen quickly [9]. Unplanned buying is categorized as pure impulse buying, in the definition diverge from a normal buying and suggestion impulse buying is the purchase when the consumer sees the product first time by seeing the quality, place, function, and use of the product as hoped.

\subsection{Hedonic shopping value}

Amanah and Pelawi [10] define hedonic shopping value as a shopping activity that aims at pleasure, and its views that shopping is an interesting thing. Hedonic shopping is also defined as shopping activity done by the consumer with friends or family only based on pleasure. It can be concluded that hedonic shopping value is a buying activity done by consumers to look for pleasure and to avoid dissatisfaction with friends and/or family and to seek comfort when shopping.

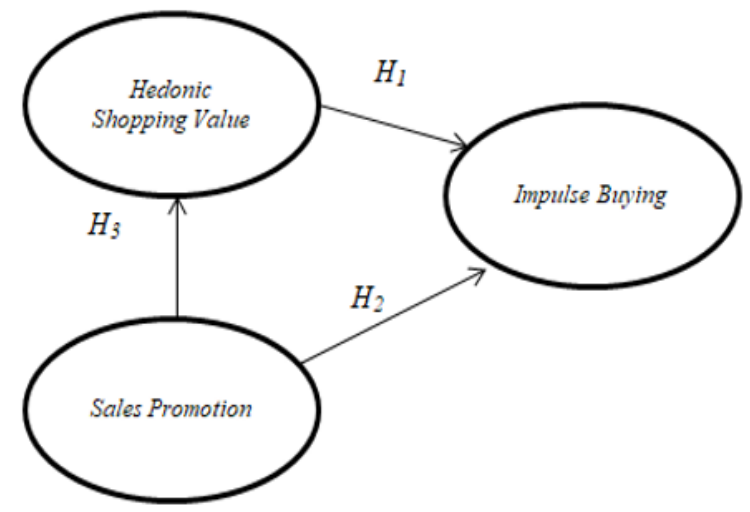

Fig. 1. Research framework 


\subsection{Hipotesis development}

\subsubsection{The relation of hedonic shopping value with impulse buying}

Andryansyah and Arifin explain that through hedonic shopping value, someone is able to choose things as he/she wants [7]. When shopping, someone has a positive emotion that appears from hedonic shopping value and makes him/she wants to buy the product unplanned.

The other research by Setyaningrum, Arifin, and Yulianto concludes the same result that hedonic shopping value significantly and positively influences impulse buying [9]. When shopping, sometimes someone does unplanned shopping or shopping, which is not on the shopping list. An interesting offer, such as sales promotion or discount, is able to make the consumer shop more from the shopping list. This interesting offer triggers hedonic shopping value to consumers, and this influences the impulse buying decision.

Kosyu et al., explain that hedonic shopping value describes the value of shopping experience covering fantasy, stimulating sensory, excitement, pleasure, curiosity, and delusion of excitement [8]. The consumer's excitement of hedonic shopping is a behavior to shop unnecessarily. Based on some previous research, the hypothesis of this research related to hedonic value and impulse buying is:

$H_{1}$ : Hedonic value has positive influences significantly toward impulse buying

\subsubsection{The relation of sales promotion toward impulse buying}

Amanah and Pelawi explain that sales promotion has significantly positive influences on impulse buying [10]. The more interesting the sales promotion, the more consumers attracted to make a buying decision. In this case, it is impulse buying. The seller should understand thoroughly how to trigger impulse buying by strategic promotion. One of them is by offering discounted price or limited time discounted price. It impacts significantly in the frequent of impulse buying.

Amara and Kchaou have the same opinion where sales promotion has a positive influence significantly toward impulse buying [14]. This means the quality and attractiveness of the sales promotion program increase the consumer's impulse buying. $\mathrm{H}_{2}$ : Sales promotion has a positive influence significantly toward impulse buying.

\subsubsection{The relation of sales promotion toward hedonic shopping value}

Mamuaya studies that sales promotion significantly as a positive influence toward hedonic shopping value [15]. It is explained that sales promotion basically is done to trigger the purchase as many as possible. A sales promotion strategy is designed solely to attract consumers to buy, and it makes sales promotion has a positive influence significantly toward hedonic shopping value.

Ramakrishna also agrees that sales promotion has a positive influence significantly toward hedonic shopping value [16]. Sales promotion is explained as a trigger of hedonic shopping for consumers. When consumers see a variety of interesting sales promotions, they will be influenced to buy more and unconsciously becoming hedonic. Based on these previous research, the hypothesis of the relation of sales promotion toward hedonic shopping value is:

$H_{3}$ : Sales promotion has positive influence significantly toward hedonic shopping value

\subsubsection{Hedonic shopping value as Intervening Variable}

Hedonic shopping value as an intervening factor influences impulse buying. Hedonic shopping value, in this case, acts as a trigger of impulse buying. Basically, the hedonic 
value comes from some factors. One of them is an impulsive attitude related to the buying process. The higher the hedonic shopping value, the higher the chances the buying process is done. Ramakrishna has the same explanation that hedonic shopping value is appeared because of sales promotion offered that makes impulse buying happens [16]. In this case, hedonic shopping value acts as an intervening variable between sales promotion variables toward impulse buying.

H4: Hedonic shopping value acts as an intervening variable that strengthens the relation between sales promotion and impulse buying

\section{Methods}

This research employs quantitative methods with causal design. The population of this research is fashion online shopping website consumers who are not able to be well defined. By using the judgemental sampling technique and Lemeshow's formula, the samples of this research are 96 and rounded to 100 . Only 99 of distributed questionnaires that can be processed. The criteria of the samples in this research are as follows:

i. Respondents are fashion online shopping customers.

ii. Respondents have done online fashion shopping in within one year.

$\mathrm{T}$ his research takes a primary data. Primary data is data retrieved from the first source where individual data is taken from filling out a questionnaire. This data is a result of a questionnaire about the influence of hedonic shopping value and sales promotion toward impulse buying.

The analysis technique in this research uses Partial Least Square (PLS). PLS analysis is a multivariate statistical technique that compares the double dependent variable and double independent variable. It can be used to predict the influence that happened between the relation of independent toward dependent variable [17]. PLS evaluation model is done by evaluating the outer model and inner model. The outer model defines how each indicator block related to the latent variable. While the inner model describes the relation between latent variables based on substantive theory [18].

\section{Result}

\subsection{Measuring model evaluation (outer model)}

\subsubsection{Convergent validity}

According to Hair, the rule of thumb is usually used to make an early evaluation from the factor matrix that is about \pm .30 considering to fulfill minimum level, for loading \pm .40 is considered good, and for loading $>0.50$ is considered significant practically [19].

The value for every construct is above 0.4 , and it is considered valid. The Convergent Validity also views the Average Variance Extracted (AVE) that should be above 0.5. 
Table 1. The result of convergent validity evaluation (outer loading value)

\begin{tabular}{cccc}
\hline & Hedonic shopping value & Impulse buying & Sales promotion \\
\hline X1.1 & 0.592 & 0.650 & $\mathbf{0 . 9 5 6}$ \\
X1.2 & 0.629 & 0.664 & $\mathbf{0 . 9 6 5}$ \\
X1.3 & 0.600 & 0.664 & $\mathbf{0 . 9 5 2}$ \\
X1.4 & 0.548 & 0.564 & $\mathbf{0 . 8 3 9}$ \\
Y1.1 & 0.643 & $\mathbf{0 . 7 7 3}$ & 0.573 \\
Y1.2 & 0.421 & $\mathbf{0 . 6 7 5}$ & 0.368 \\
Y1.3 & 0.771 & $\mathbf{0 . 8 8 2}$ & 0.681 \\
Y1.4 & 0.374 & $\mathbf{0 . 5 7 3}$ & 0.248 \\
Y1.5 & 0.716 & $\mathbf{0 . 8 6 4}$ & 0.639 \\
Y1.6 & 0.692 & $\mathbf{0 . 8 1 3}$ & 0.602 \\
Y1.7 & 0.689 & $\mathbf{0 . 7 6 0}$ & 0.470 \\
Y1.8 & 0.618 & $\mathbf{0 . 8 2 2}$ & 0.495 \\
Z1.1 & $\mathbf{0 . 7 6 9}$ & 0.525 & 0.402 \\
Z1.2 & $\mathbf{0 . 8 0 1}$ & 0.659 & 0.480 \\
Z1.3 & $\mathbf{0 . 8 4 3}$ & 0.644 & 0.544 \\
Z1.4 & $\mathbf{0 . 7 7 4}$ & 0.584 & 0.406 \\
Z1.5 & $\mathbf{0 . 8 6 3}$ & 0.741 & 0.537 \\
Z1.6 & $\mathbf{0 . 8 2 9}$ & 0.745 & 0.578 \\
Z1.7 & $\mathbf{0 . 8 3 8}$ & 0.720 & 0.638 \\
Z1.8 & $\mathbf{0 . 4 8 2}$ & 0.395 & 0.322 \\
\hline
\end{tabular}

Table 2. Average Variance Extracted (AVE)

\begin{tabular}{lcc}
\hline & The average variance extracted (AVE) \\
\hline Hedonic shopping value & 0.613 \\
Impulse buying & 0.602 \\
Sales promotion & 0.864 \\
\hline
\end{tabular}

The value of Average Variance Extracted (AVE) in every construct is above 0.5, and it is stated to pass the convergent validity evaluation.

\subsubsection{Reliability evaluation}

Reliability Evaluation is done to look at the consistency of a construct. It can be measured using Composite Reliability that should be more than 0.7 .

Table 3. The result of composite reliability analysis

\begin{tabular}{lcc}
\hline & Composite Reliability & Cronbach's Alpha \\
\hline Sales promotion & 0.962 & 0.947 \\
Hedonic shopping value & 0.925 & 0.906 \\
Impulse buying & 0.923 & 0.904 \\
\hline
\end{tabular}

From the table, it can be concluded that the variables have a composite reliability value that has value $\geq 0.7$, so it can be concluded that all of the variables have a high level of internal consistency reliability.

The result of the outer model analysis shows that there is a measuring model, or there is a relation by construct with the indicator. This research has three variables. There are hedonic shopping value, impulse buying, and sales promotions. 


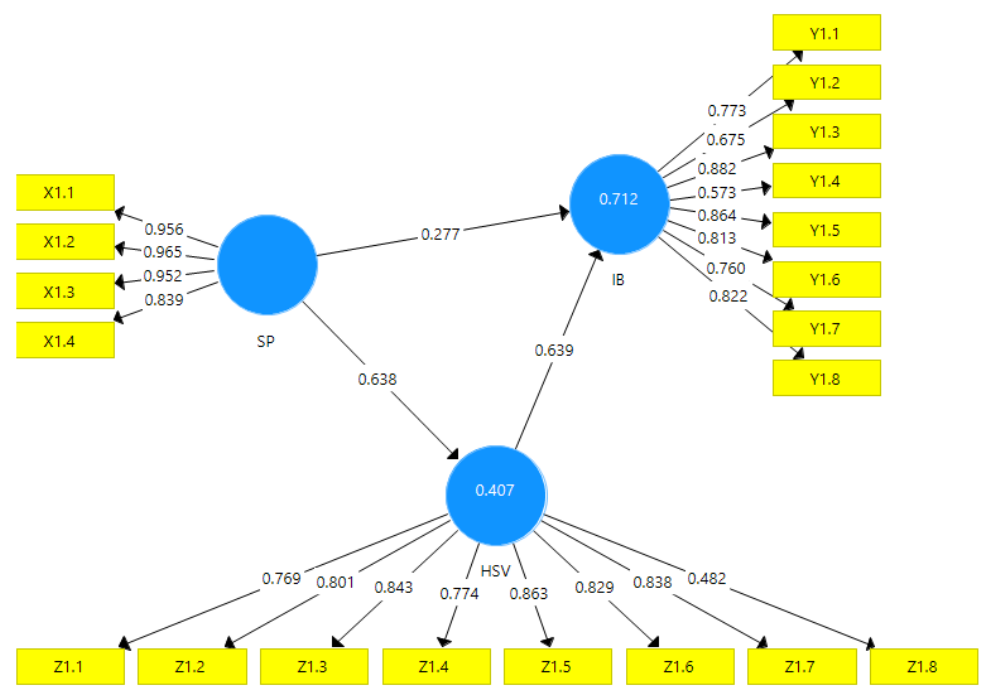

Fig. 2. The result of outer model analysis

\subsection{Inner Model}

\subsubsection{Hypothesis evaluation}

The structural model is evaluated by using a bootstrapping technique by using 5000 subsamples. The evaluation of the significant coefficient path is done by comparing $\mathrm{T}$-statistic with t-table value on a significant level $5 \%$ or about 1.96 . The coefficient path has a significant influence if T-statistic values more than 1.96 of the t-table value.

Table 4. The result of significant inner model through bootstrapping 500

\begin{tabular}{ccccc}
\hline Hipotesis & Direct Influence & Original Sample (O) & T Statistics $(\mid \mathbf{O} /$ STERR|) & P Values \\
\hline $\boldsymbol{H}_{\boldsymbol{I}}$ & HSV IB & 0.639 & 7.105 & 0.000 \\
$\boldsymbol{H}_{\mathbf{2}}$ & SP IB & 0.277 & 2.838 & 0.000 \\
$\boldsymbol{H}_{\mathbf{3}}$ & SP HSV & 0.638 & 9.707 & 0.000 \\
\hline
\end{tabular}

\subsubsection{Coefficient determination}

The $\mathrm{R}^{2}$ value is used to measure the variety changing the level of an exogen variable toward the endogen variable. The higher the $\mathrm{R}^{2}$ value, the better the prediction model from the submitted research model [17].

Table 5. $\mathrm{R}^{2}$ value

\begin{tabular}{ll}
\hline & $\mathrm{R}^{2}$ \\
\hline HSV & 0.407 \\
IB & 0.712 \\
\hline
\end{tabular}

\section{Discussion}

The result of this research shows that hedonic shopping value has a positive influence significantly toward impulse buying marked by T-statistic 7.105. It confirms the previous research [7-9] that the consumers' hedonic shopping value is viewed to make the impulse buying 
Hedonic shopping value is a buying process done by consumers to look for pleasure and to avoid dissatisfaction with friends and/or family and to seek comfort when shopping [10]. From mean value analysis, it can be concluded that the respondents have a tendency to doing hedonic shopping. It shows in the high mean value, that states, "the more things I buy, the happier I get." The respondents are dominated by the young generation that assumes shopping is entertainment and happy to shop more. The tendency of people to go shopping happily and entertained makes them go shopping. Based on the evaluation result, it can be concluded that there are influences between variables.

The result of this research shows that sales promotion has a positive influence significantly toward hedonic shopping marked by the T-statistics value 9.707 . The result confirms the study of $[10,14]$ which means that sales promotion done by online fashion shopping is effective in triggering the respondent's hedonic shopping value in this research.

The sales promotion is usually done by giving discounted prices, cashback, bundling products, and shopping coupons. Amanah and Pelawi describe that the determination of the sales promotion strategy is important to make the consumers keep shopping and it gives benefits to the company [10]. In this research, consumers are aware of all the strategies of fashion online shopping. This shows in the mean value analysis from the sales promotion variable which is classified in agreeing on category. Consumers are already interested in the cashback program as a sales promotion program, and it has a tendency to increase hedonic shopping value.

The result of this research also shows that sales promotion has a positive influence significantly toward impulse buying, marked by T-statistic value 2.838 . It confirms the research of $[15,16]$ that sales promotion done by online fashion shop increases the consumer's impulse buying.

The high mean value of impulse buying in this research marked by the total mean variable of impulse buying that is classified in the agreeing category. The statement about the tendency to purchase an unowned products from an online fashion shop impulsely is the statement with the highest mean value in impulse buying variable. This variable strengthens impulse buying phenomena, in this research, it is influenced by the desire to have the product of online fashion shop and not yet owned by the consumers.

The calculation result of indirect influence shows that its value is 0.407682 higher than direct influence 0.277 . This confirms the research of Ramakrishna that hedonic shopping value acts as intervening that gives influence from sales promotion toward impulse buying [16].

As explained, the sales promotion program that is the most attracting respondents is the cashback program given by the online fashion shop, which is supported by the respondents' hedonic shopping value. It is shown from the statement about the more products bought, the happier they get. This strengthens the increasing tendency to buy impulsely because basically, the seller is already preparing the sales promotion program that is liked by the hedonic shopping value consumers.

\section{Conclusion}

Sales promotion is important to determine the consumers buying decision. The interested consumers of the cashback program as a sales promotion program have a tendency to increasing hedonic shopping value. Hedonic shopping value is next to Influence increasing impulse buying.

To increase the selling, the owner of the online fashion shop needs to pay attention to the sales promotions, such as cashback programs or bundling products, to increase the consumers' interest to buy impulsively. In the next research, the number of samples needs to be increased to get more measurable results. 


\section{References}

1. Y. Yusra, Rencana bisnis Berrybenka tahun 2016. [Online] from https://dailysocial.id/post/berrybenka-dan-rencana-bisnisnya-di-tahun-2016 (2016). [in Bahasa Indonesia].

2. I.L. Sugih, S. Soekarno, Social and Behavioral Sciences 169:240-248(2015). https://core.ac.uk/download/pdf/82774431.pdf

3. Kemenperin, Perluas Pasar Industri Fesyen Dalam Negeri Lewat Indonesia Fashion Week 2018. [Online] from http://www.kemenperin.go.id/artikel/19010/Perluas-PasarIndustri-Fesyen-DalamNegeri-Lewat-Indonesia-Fashion-Week-2018 (2018). [in Bahasa Indonesia].

4. P.T. Lai, P. Sung, International Journal of Economics and Management Engineering, 8,7:1-3(2014). https://pdfs.semanticscholar.org/1d1f/c48befe14164db4aae28b8b842f5930756bc.pdf

5. N. Ahmad, A. Omar, T. Ramayah, Business Strategy Series, 11,4:227-243(2010). https://www.researchgate.net/publication/235262100_Consumer_lifestyles and onlin e shopping continuance intention

6. R.R. Ridha, F.S. Prabowo, E-Proceeding of Management, 2,3:2878-2884(2015). [in Bahasa Indonesia]. https://openlibrary.telkomuniversity.ac.id/pustaka/files/104579/jurnal_eproc/pengaruh -motivasi-belanja-utilitarian-dan-hedonis-terhadap-preferensi-pembelian-online-padaline-shopping.pdf

7. M. Andryansyah, Z. Arifin, Jurnal Administrasi Bisnis, 57,1:111-120(2018). [in Bahasa Indonesia].

http://administrasibisnis.studentjournal.ub.ac.id/index.php/jab/article/download/2479/ $\underline{2870}$

8. D.A. Kosyu, K. Hidayat, Y. Abdillah, Jurnal Administrasi Bisnis, 14,2:1-7(2014). [in Bahasa Indonesia].

http://administrasibisnis.studentjournal.ub.ac.id/index.php/jab/article/view/597

9. F. Setyaningrum, Z. Arifin, E. Yulianto, Jurnal Administrasi Bisnis, 37,1:97105(2016). [in Bahasa Indonesia]. http://administrasibisnis.studentjournal.ub.ac.id/index.php/jab/article/view/1432

10. D. Amanah, S.P. Pelawi, Jurnal Quanomic, 3,2:10-17(2015). http://digilib.unimed.ac.id/14613/

11. G. Windiarto, Jurnal Manajemen dan Bisnis, 10,1:1-8(2014). [in Bahasa Indonesia]. http://ejournal.umpwr.ac.id/index.php/segmen/article/view/1259

12. L.A. Darma, E. Japarianto, Jurnal Manajemen Pemasaran, 8,2:80-90(2014). [in Bahasa Indonesia]. http://jurnalpemasaran.petra.ac.id/index.php/mar/article/view/19185

13. O.G. Kwan, Jurnal Manajemen Pemasaran, 10,1:27-35(2016). [in Bahasa Indonesia]. http://jurnalpemasaran.petra.ac.id/index.php/mar/article/view/19771/19011

14. R.B. Amara, A.S. Kchaou, International Journal of Management Excellence 3,1: 362-373(2014). https://pdfs.semanticscholar.org/01f4/52112e9d2f7058fe2c23e322bea99a95f69f.pdf

15. N. Maumaya, Derema Journal Manajemen, 13,1:83-99(2018). https://ojs.uph.edu/index.php/DJM/article/view/785

16. S. Ramakrishna, Indian Journal of Research, 4,10:2250-1991(2015). https://www.worldwidejournals.com/paripex/recent_issues_pdf/2015/October/October 2015_1444990591_87.pdf 
17. J. Hartono, W. Abdilah, Konsep dan aplikasi PLS (Partial Least Square) untuk penelitian empiris. [The concept and application of PLS (Partial Least Square) for empirical research], Yogyakarta: BPFE Yogyakarta (2009). [in Bahasa Indonesia]. https://www.belbuk.com/konsep-dan-aplikasi-pls-partial-least-square-untukpenelitian-empiris-p-20699.html

18. I. Ghozali, Structural Equation Modeling Metode Alternatif dengan Partial Least Square (PLS). [Structural Equation Modeling Alternative Methods with Partial Least Square (PLS)], Semarang: Badan Penerbit Universitas Diponegoro, (2011). [in Bahasa Indonesia]. https://digilib.undip.ac.id/v2/2012/10/04/structural-equation-modelingmetode-alternatif-dengan-partial-least-square/

19. J.F. Hair, W.C. Black, B.J., Babib, R.E. Anderson, Multivariate data analysis: A global perspective, New Jersey: Pearson Education, Inc (2010).

https://www.pearson.com/us/higher-education/program/Hair-Multivariate-DataAnalysis-7th-Edition/PGM263675.html 